\title{
'In this country my children are learning two of the most important languages in Europe': ideologies of language as a commodity among Greek migrant families in Luxembourg
}

\section{Nikos Gogonas \& Claudine Kirsch}

To cite this article: Nikos Gogonas \& Claudine Kirsch (2016): 'In this country my children are learning two of the most important languages in Europe': ideologies of language as a commodity among Greek migrant families in Luxembourg, International Journal of Bilingual Education and Bilingualism, DOI: 10.1080/13670050.2016.1181602

To link to this article: http://dx.doi.org/10.1080/13670050.2016.1181602

\section{Published online: 18 May 2016.}

Submit your article to this journal ¿

\section{Цll Article views: 83}

Q View related articles $\longleftarrow$

View Crossmark data \lceil 


\title{
'In this country my children are learning two of the most important languages in Europe': ideologies of language as a commodity among Greek migrant families in Luxembourg
}

\author{
Nikos Gogonas and Claudine Kirsch \\ Institute of Applied Educational Sciences, Université du Luxembourg, Maison des Sciences Humaines, Esch sur \\ Alzette, Grand Duché du Luxembourg
}

\begin{abstract}
This paper explores the language ideologies of three middle-class migrant Greek families in Luxembourg, one 'established' family and two 'new' crisis-led migrant families, all of whose children attend Luxembourgish state schools. While the families differ in terms of migration trajectory, their language ideologies converge. The findings of this ethnographic study show that all parents view multilingualism as an asset and relate it to culture, identity and job opportunities. The parents' ideologies are shaped both by their desire to improve their social standing and by societal discourses on the values of languages in the job market and in the Higher Education. Luxembourg's official trilingualism is seen as a symbol of national cohesion and it is viewed as a commodity on the job market. Thus, the development of children's multilingualism in French, German and English is seen as a 'commodity' which, they hope, will enable children to compete in the new globalised, transnational and post-industrial/services market.
\end{abstract}

\section{ARTICLE HISTORY}

Received 18 October 2015

Accepted 15 April 2016

\section{KEYWORDS}

Language ideologies; Greek migrants; Luxembourg

\section{Introduction}

The European South, which had only recently become a destination for immigration, seems to be experiencing a new major emigration wave due to the post-2009 financial crisis. This is especially true of Greece, the country which has been hit hardest by the economic crisis and concomitant austerity measures.

Greeks have a long history of emigration and many studies report on their language maintenance/ shift patterns in the diaspora. Paulston (1986), for example, found that the Greek community of Pittsburgh, USA, maintained the Greek language for four generations, breaking thus the 'three generation rule' in the US, noted by researchers such as Fishman (1966), Veltman (1983) and Paulston (1986). Similarly, in the Australian context, Greeks viewed the heritage language as a core value for their identity and were committed to its maintenance (Smolicz and Secombe 1988; Smolicz, Secombe, and Hudson 2001). At the beginning of the twenty-first century they displayed the strongest degree of ethnolinguistic vitality of all ethnic groups in Australia (Tamis 2005, 2009). Greek immigrants in Germany were found to be a highly language-maintenance-oriented group (Chatzidaki 1996). By contrast, studies in Belgium (Chatzidaki 1996) and in the Netherlands (Dialektopoulos 2003) depicted the Greek communities as rather negligent of ethnic language maintenance. Language ideologies are the driving force behind language management and family language policies in contexts of migration (Curdt-Christiansen 2009). One wonders to what extent ideologies are shaped by the migrants' 
socioeconomic status and their motivation for emigrating. Most of the sociolinguistic studies on Greeks abroad refer to post-war emigrants from Greece to the US, Australia and Northwestern Europe who were mostly working class and unqualified (Triandafyllidou and Gropas 2014). According to Triandafyllidou and Gropas (2014), the new migration from southern Europe is qualitatively different. Current new emigrants are highly qualified and strongly motivated by career prospects. The present paper investigates the language ideologies of Greek families in Luxembourg. The study is original in a number of ways. First, few studies have researched the new crisis-led emigration from Southern Europe. The present study is one of the first on the new crisis-led migration from the South to the Northwest of the European Union (EU). Second, in multilingual Luxembourg, there is a dearth of sociolinguistic studies of linguistic minorities other than the Portuguese, the biggest community in the country. This is despite the fact that almost $40 \%$ of the population is non-Luxembourgish. Therefore the present study is filling a research gap in the literature on migrant languages in Luxembourg.

Luxembourg has attracted middle-class Greek migrants since the 1960s. Many Greeks came to Luxembourg as employees in the European Institutions and the NATO. By contrast, the newly arrived Greek immigrants have to find work on the wider job market. Immigrating to Luxembourg poses a challenge for both adults and children, as the country has three officially recognised languages and a trilingual educational system with Luxembourgish, German and French. The paper focuses on three Greek families. It examines their ideologies and their beliefs regarding the value and the role of their ethnic language and the languages of Luxembourg and it investigates the factors that shape these beliefs.

\section{Ideologies of language as a commodity in the globalised new economy}

Woolard $(1998,3)$ has defined language ideologies as 'representations, either explicit or implicit, that construe the intersection of language and human beings in a social world'. Ideologies of language are, therefore, always socially situated and tied to questions of identity and power (Woolard 1998). According to Kroskrity's (2004) definition they are 'constructed from the sociocultural experience of the speaker'. With the onset of the age of late capitalism within the globalised new economy (Giddens 1991; Appadurai 1996; Gee, Hull, and Lankshear 1996; Pujolar 2007), neoliberalism constitutes a major sociocultural influence for modern-day migrants (Park and Lo 2012; Woo Lee 2016). The neoliberal ideology places commodities at the centre of 'its social world' (Holborow 2015, 31). Heller (2003, 2010), Tan and Rudby (2008) and Duchêne and Heller (2012) are among those who have addressed the relationship between language and political economy. Heller (2003) introduced the term 'commodification of language' to refer to the exchange value of language on the job market. Language commodification has a particular role in the language industry and has been studied frequently in call centres. In Quebec, for example, the French minority workers were trained to use a particular type of French vocabulary and communication style in order to come across as professionals (Da Silva, McLaughlin, and Richards 2007). On the transnational or global linguistic market, English is a highly valued commodity (Cameron 2012). Referring to the call centres in Pakistan, Rahman (2009) explains the strategies used to increase business with the US. The workers attended accent naturalising training in order to be able to 'put on' a US accent and to pass for American native speakers. As a result of the rise of English as the de facto lingua franca in the world today, a new bi/multilingualism has arisen, one in which English is the key language, added onto one or more languages acquired in early childhood, socialisation and education (Block 2014). According to Block (2014) this kind of multilingualism is linked to the development of the 'neoliberal citizen' linking neoliberal economic policies with the development of cosmopolitan citizenship in education. This is expressed by a growing interest in individual multilingualism, especially among the middle class in countries such as Switzerland and Canada (Block 2014, 151). Moreover, many Asian middleclass families resort to transnational educational migration in order to ensure better English language education for their children and, thus, better chances on the job market (Huang and Yeoh 2005; Chew 
2010; Park and Lo 2012). However, the language ideologies of families are not only driven by utilitarian motives but also by cultural ones. Duchêne and Heller's (2012) concepts of 'pride' and 'profit' help explain why people wish to maintain or develop particular languages. The notion of 'pride' relates language to cultural or national belonging while the notion of 'profit' views language as an economic element, such as a source of added value. Both notions are intertwined and influence the conception of language although the notion of profit has been the more dominant one since the 1990s (Heller and Duchêne 2012, 3-4). Brennan (2013) illustrates the complex relationship between 'pride' and 'profit' by focusing on Irish. While the promotion of Irish was once constructed in both cultural and political terms, it is today at the heart of economic discourses. In Luxembourg, multilingualism is rooted in its history, allows for integration and counts as an economic asset.

\section{Multilingualism as a commodity in Luxembourg}

Luxembourg is frequently portrayed as the country of the EU that fosters multilingualism par excellence (Horner 2011). This image has to be seen in relation to both the 1984 language law that recognised Luxembourgish, French and German as the country's official languages and to the trilingual educational system (Horner 2011). The educational system has a long history of valuing multilingualism as a 'resource'. The Education Act of 1843 introduced mandatory instruction in French alongside German in primary schools (Weber 2009). The teaching of Luxembourgish was introduced in 1912. While Luxembourgish is equated with the 'home language' (of some children only), German and French (and increasingly English) are viewed as sources of linguistic capital acquired both inside and outside the classroom. Official discourses have constructed multilingualism at a national level as a symbolic pillar of national cohesion and at a personal level as a valuable asset in that it is 'a commodity with obvious exchange value on the job market' (Horner and Weber 2008, 120). Learners develop a valuable and marketable multilingual repertoire. However, not all languages and registers are legitimated. Horner (2011) maintains that societal multilingualism constitutes a problem especially if it breaks away from the specifically prescribed trilingual (plus English) paradigm. In her words:

Significantly, the language as resource discourse indexes the mastery of written, standardized forms of language and thus bears similarities to the commodification of language, which in turn does not acknowledge nor valorize the diverse linguistic repertoires of many people. $(2011,492)$

Multilingualism in Luxembourgish, German, French and English (as well as high literacy skills) are necessary in order to get a state job. A good mastery of German or French and English is relevant in banks. The importance of competence in Luxembourgish has increased and some transborder workers from the neighbouring countries have begun to attend Luxembourgish language courses in order to increase their employment opportunities in Luxembourg. As we will show later, the Greek parents in this study are both aware of the Luxembourgish 'linguistic market' and of the fact, that Greek is not a valued repertoire. Therefore, they all improve their skills in several languages. In addition, they perceive migration to Luxembourg as an educational investment for their children. They aspire that their children will become multilingual like the Luxembourgers and they want them to master, among others, English, as well as know Greek. The next section examines the nature of Greek migration to Luxembourg.

\section{Crisis-led migration from Greece}

The phenomenon of emigration from Greece is not new. The first wave was observed after the Second World War and involved mainly scientists and artists who contributed intellectually to the reformation of Europe (Labrianidis and Vogiatzis 2013). During the 1960s, there was a mass exodus of unskilled migrants who left for Western Europe (Germany), Australia, Canada, and the USA as 'blue-collar' workers (Labrianidis and Vogiatzis 2013). A third outflow of Greek emigrants 
took place during the Greek military dictatorship (1967-1974) for political reasons. However, this flow was gradually reversed following the economic reconstruction of Greece during the 1980s (Labrianidis and Vogiatzis 2013). At present, the European South is experiencing a new major emigration wave due to the post-2009 financial crisis. Over the past five years, an estimated 200,000 Greeks, or $2 \%$ of the nation's population, have left the country. In contrast to post-war immigrants from Greece to Northwestern Europe who were mostly working class and unqualified, the current emigrants are highly qualified and motivated by career prospects amongst other factors (Labrianidis and Vogiatzis 2013). According to a European University Institute report, $88 \%$ of those who left hold a university degree (e.g. over 60\% a master's degree and 11\% a PhD) (Triandafyllidou and Gropas 2014). Statistics further show that $79 \%$ of the emigrants were employed at the beginning of the crisis. They decided to leave because they felt the country lacked perspectives for development and they had few professional opportunities. In 2011-2012 the number of Greeks moving to EU countries increased by $170 \%$ compared to 2007-2008 (Triandafyllidou and Gropas. 2014). A large percentage of families with children have already left Greece and many more are preparing for migration (Nikolaou 2013).

Greek migration to Luxembourg started in the 1960s and has been closely related to job opportunities at the European Institutions where the Greeks were employed as EU civil servants (DrouliaMitrakou 2006). In essence, it was a middle-class migration. Greek EU employees usually enrolled their children at the Greek section of the European School. In 2001 there were 865 Greek citizens in Luxembourg. Over the years and especially after the economic crisis, immigration has more than doubled and the Greek population numbered 2108 in 2014 (www.statistiques.public.lu). Unlike previous Greek migrants, the more recent ones tend to enrol their children in trilingual state Luxembourgish schools. Given the current crisis and the increasing Greek migration to Luxembourg, the present project investigates how current socio-political and cultural contexts impact on the language ideologies of transnational Greek families in Luxembourg. The study addresses the following research questions: What are Greek parents' language ideologies in multilingual Luxembourg and what are the factors that shape them? How do language ideologies inform their language use and policies?

\section{Methodology}

In order to collect in-depth data and to understand language ideologies from an insider's perspective, we adopted a qualitative methodology and opted for a small sample. This ethnographic study scrutinises the dynamic qualities of a situation, that is, Greek migrant parents' language ideologies and family language policies in multilingual Luxembourg. The researcher's close relationship with the participants justifies the small sample and the quality and density of the data enhance the validity of the fine-grained, in-depth inquiry. Thus, the small size is not incompatible with the theoretical underpinnings of the study and has little bearing on the project's basic logic (Crouch and McKenzie 2006).

\section{Participating families}

We chose the participants according to the following criteria: (a) families where both parents are Greek, (b) families with children attending state Luxembourgish schools, (c) families with a different length of residence in Luxembourg. Our aim was to compare the 'established' and 'new' families. The participants were recruited from the Greek community in Luxembourg and the Greek complementary school. This paper focuses on three families, an 'established' one living in Luxembourg for 9 years and two 'new' families who arrived in Luxembourg approximately 15 months before the study was conducted. Table 1 provides an overview of the families.

Family A has a 9-year-old daughter, Katerina (all participants are given pseudonyms), and a 19year-old son who lives in Germany. Katerina was born in Luxembourg. The mother, Fani (53), came to Luxembourg in 2005, following her husband Stefanos (56) who took up the offer of a job at NATO.

She studied German language and literature in Greece and holds an MA in educational management from a British university as well as an MA on Teaching German as a foreign language from a 
Table 1. Participating families.

\begin{tabular}{|c|c|c|c|}
\hline & Family A (established) & Family B (new) & Family C (new) \\
\hline $\begin{array}{l}\text { Parents' names and } \\
\text { ages }\end{array}$ & Stefanos, 54 and Fani, 53 & Maria, 40 and loannis, 46 & Sofia, 37 and Kostas, 37 \\
\hline $\begin{array}{l}\text { Children's names } \\
\text { and ages }\end{array}$ & $\begin{array}{r}\text { Katerina, } 9 \\
\text { Nikos } 20\end{array}$ & $\begin{array}{l}\text { Eleni, } 8 \\
\quad \text { Alexandra, } 11 \\
\text { Ariadne, } 13\end{array}$ & $\begin{array}{l}\text { Stefanos, } 7 \\
\quad \text { Thomas, } 5.5\end{array}$ \\
\hline Time in Luxembourg & 9 years & 16 months & 15 months \\
\hline Parents' education & Master's degrees & $\begin{array}{l}\text { Ioannis: Post-secondary } \\
\text { vocational education. } \\
\text { Maria: University degree }\end{array}$ & $\begin{array}{l}\text { Kostas: Technical University } \\
\text { Degree } \\
\text { Sofia: Post-secondary } \\
\text { vocational education }\end{array}$ \\
\hline Parents' occupations & $\begin{array}{l}\text { Stefanos: Official in an international } \\
\text { organisation } \\
\text { Fani: Language teacher at the } \\
\text { European Parliament }\end{array}$ & $\begin{array}{l}\text { loannis: Hotel employee } \\
\text { Maria: unemployed }\end{array}$ & $\begin{array}{l}\text { Kostas: IT specialist European } \\
\text { Parliament } \\
\text { Sofia: Graphics designer at a } \\
\text { company }\end{array}$ \\
\hline
\end{tabular}

Greek university. In Greece she worked as a secondary school teacher and teacher-trainer. In Luxembourg, she works as a teacher of Modern Greek for interpreters at private language school.

Family B has three daughters, Eleni (8), Alexandra (11) and Ariadne (13). The two younger girls attend primary school while the eldest girl attends a technical secondary school. Their mother Maria (40) is unemployed. She holds a Bachelor's degree in Greek culture. Her last jobs in Greece were in administration and the service sector. Her husband loannis (46) studied hotel management in Switzerland and decided to come to Luxembourg after securing a job at a hotel. He came to Luxembourg in November 2012 and his family joined him 7 months later, in June 2013.

Family C came to Luxembourg in July 2013. They have two sons, Stefanos (7) and Thomas (5.5), both born in Greece. Sofia, the mother, studied graphics and worked in a graphic arts workshop in Athens. In Luxembourg, she was at first unemployed but in the course of the study she found employment as a graphics designer. Her husband Kostas used to work as an IT specialist at a Greek Telecommunications Company. He currently works as an IT external collaborator at the European Parliament in Luxembourg.

\section{Data collection and analysis}

Methods of data collection included participant observation, informal conversations and interviews with parents and children over a period of 8 months. All interviews were conducted in Greek. On various occasions, collaborative ethnography was employed: parents and children audio/video-recorded routine family interactions. In the subsequent meetings, they explained the recordings thereby contextualising the data. Finally, the data included field notes and other documents (e.g. pictures taken during the home visits and emails from parents). The data presented in this paper are drawn from 900 minutes of transcribed interviews and audio and video recordings. The data analysis followed many of the characteristics of the grounded theory paradigm (Bernard and Ryan 1998; Charmaz 2006; Corbin and Strauss 2008): the data were reviewed, coded and thematically analysed according to the common issues and patterns that emerged. The themes included awareness of the socio-economic and political context, beliefs regarding the value of languages, reasons for learning languages, ways of developing languages, and similarities and differences in relation to families and languages. Critical discourse analysis was applied to analyse the parents' language ideologies in more depth.

\section{Findings: language ideologies and language use in the present and the anticipated future}

The next sections will illustrate the language ideologies of the parents. All parents believe multilingualism to be an asset and an achievable target for both their children and themselves. They have 
a positive and dynamic view of bilingualism, which contrasts with the dominant ideology according to which the simultaneous development of several languages is detrimental to the development of the majority language. As Luxembourg is multilingual and as the children have to cope with three official languages (as well as English) the parents are very conscious of the effort it takes to master all and seek opportunities to learn languages formally and informally. They have high aspirations for the children and support them in diverse ways. They are acutely aware of the value that languages hold for integration, for the development of a cultural identity and for a career. As will be seen in the final sections of the findings, they consider the value of English in relation to citizenship and the global market and that of Greek in relation to both career prospects and identity.

\title{
Parents as multilingual learners/users
}

This section discusses the parents' multilingual skills and illustrates their endeavours and opportunities to develop these further. Fani (family A) is fluent in German, has very good Luxembourgish and English, and a little French. Her language skills and her motivation to learn have enabled her to integrate smoothly and quickly in Luxembourgish society. She explains:

\begin{abstract}
I sat the B1 exam in Luxembourgish and I did great, and on 24th of June (2015) I am sitting the B2 level because the B1 exam was too easy for me that I am sure I am going to pass B2 too. When I started having Luxembourgish lessons I never played anything else in the car radio apart from Luxembourgish language radio stations. I am also involved in social activities, exchanges etc, with my daughter's school, with her friends and teachers, and so on. I also read the national press as I master German. (Fani)
\end{abstract}

Her husband Stefanos learned German and French for several years and briefly studied Luxembourgish. He feels most confident in English which he speaks well and uses at work. According to Fani:

\begin{abstract}
He mostly reads English. If he is at an airport for example he may read the Economist. English is his strongest foreign language and he's very good at it, he is fluent. It's also the language of his work. For example, even though he's been having French lessons for 4 years he still doesn't feel comfortable with it. When Stefanos listens to English in the car I tell him 'how do you expect to learn French like this?' (Fani)
\end{abstract}

The excerpt above shows that Stefanos does not have Fani's integrative motivation for learning Luxembourg's three languages to a high standard. He has a permanent position in an international organisation where English is the work language and he is under no pressure to improve his skills in other languages.

By contrast, the parents of the other families who have recently migrated to Luxembourg have a higher degree of insecurity regarding employment prospects. They know they must improve their language skills. Sofia (family B) speaks Italian and English and is currently learning French at the National Institute of Languages. She speaks English at work, as does her husband Kostas, but has less confidence. Kostas states that unlike him - he never misses opportunities to practice the languages he knows - she takes no risks. He states:

I am really concerned because Sofia doesn't use the languages at all. Imagine, she knows Italian and has never used it in Luxembourg while she has had many opportunities. Now she's found a job where she has to use English and I hope this will do her good. However, I have found a native English teacher for her because she needs extra practice. She needs to improve her English. (Kostas)

Ioannis (family C) speaks English, German and French. He attends an intensive Luxembourgish language course and studies German on his own. He insists on improving his language skills in order to secure his job position and to be prepared for future job opportunities. His wife Maria speaks English and German well. She attended German language courses for several years in Greece and currently attends an advanced class in Luxembourg. She is also enrolled in a beginners' French course at the same Institute. Her inability to find employment in Luxembourg in spite of her multilingual skills leaves her feeling disillusioned. loannis comments as follows: 
My wife speaks German, English, and Greek. Her French isn't so good and sometimes she can't get a job because of that. This is the reason why she is attending French courses. I think this is an investment for her. I encourage her. (loannis)

The theme of language learning as 'investment' permeates the parental discourse on themselves and their children as illustrated in the following sections. Norton (2013) maintains that learners who 'invest' in the target language do so with the understanding that they will acquire a wider range of symbolic and material resources which, in turn, will increase the value of their cultural capital and social standing.

\section{Trilingual schooling as an investment for language learning and upward mobility}

Parents from all three families feel content with their migration project and express very positive attitudes to life in Luxembourg. According to their discourse, Luxembourg is a country characterised by high living standards, security, organisation, amenities for families, and good quality (multilingual) state school education. According to loannis, the high quality education system was the main reason why he wanted his family to join him in Luxembourg. He could have supported his family financially from Luxembourg while they remained in Greece. In the following excerpt, loannis explains why he preferred his daughters to attend a state-school to the European school:

As soon as I arrived here alone, I checked the European schools out and I came to the conclusion that my children would go to Luxembourgish school. Because, if they learn Luxembourgish, French and German then they will be able to talk to anybody. But if they remain within a 'Greek circle' they will do some courses in other languages with international kids but this is not enough for me. I don't have any complaints about the teachers in Luxembourgish school. They work really hard. My children are learning two of the most important languages of Europe; French and German. These languages are practically spoken in half of Europe. (loannis)

His wife Maria expresses similar views: Attending trilingual education with the 'important languages' of Europe is an important toolkit for the children's future academic and employment plans:

Apart from the fact that the European School is expensive, I don't think it would be any use for them, as we live in Europe and we have a future here, I think they can learn more useful things than the Greek language or the subjects they would learn at a Greek school. (Maria)

Kostas is equally happy about his two sons attending a state school. He believes that the knowledge of Luxembourgish and the immersion in the local culture will help his sons integrate. In addition, he argues that learning new languages helps them develop the essential skill of 'adaptability', which prepares them for the international job market:

For me, the key is 'adaptability' and this is a skill they are learning through growing up here. If they have to learn Chinese at some point in their lives because they found a good job opportunity, they will be able to do so and they won't hesitate. (Kostas)

He considers the Greek section of the European school as an option for secondary education, in case the children do not achieve high grades upon completion of their primary school. However, he also believes that the German section is worth considering as immersion in this 'international language of economy' might open up further opportunities.

In the same vein, Fani appreciates the trilingual Luxembourgish education system for opening up a lot of options to her daughter. Having been born in Luxembourg, Katerina is fluent in Luxembourgish and German. Her parents have noticed that she is 'talented for languages' and, therefore, they would like her to learn 'as many languages as possible' in line with her likely future professional needs.

I consider these three (Luxembourgish, German, French) as a minimum basis. Actually it should be German, French, English, Luxembourgish as minimum and from then on she should also learn additional languages. [ ... I If she is to study in France, l'd rather her French were stronger. For example if she wants to study law,

France has a different law system from Germany. (Stefanos) 
In the excerpt above Stefanos voices his high expectations regarding Katerina's future career and aspires to build on her already rich linguistic repertoire by adding even more languages. The following section illustrates that the parents also wish their children to develop skills in English on top of learning Luxembourgish, German and French at school and of using Greek at home.

\section{English as a vehicle for cosmopolitan citizenship and as a commodity in the global market}

As previously shown, English plays a vital role in the jobs of Stefanos and Kostas. In the excerpt below, Kostas's defence of English reaches the point where he criticises ethnocentric Greek language ideologies (see Moschonas 2004). In essence, he tackles the issue of the non-acceptance of non-translated English documents in Greece and links the widespread acceptance of English to 'Europeanisation':

My work is in English, I was using it also for my work in Austria. I don't work with native English speakers, but my written language is good, I make presentations, etc. My level is good. I have also communicated in English here in Luxembourg in public services, etc., and people tell me 'I'm sorry, I don't speak good English' but I tell them 'don't worry, you speak very well, even accepting to use English is great'. This is something else that I like here, that while English is not an official language, they accept official untranslated documents in English. This would be a great reform if it was done in Greece. This would mean 'Europeanization'. (Kostas)

Kostas believes that a 'European citizen' has excellent English skills. He views himself as a 'European citizen' and as a 'citizen of the world' and has the same aspirations for his sons even if this means putting pressure on them:

If we would like to think of Stefanos as a 'European citizen', then both Luxembourgish and Greek are useless. He could manage with English in both countries realistically talking ( ... For English I am going to insist. It is the only language that I am going to put pressure on them to learn. I can see how English has helped me to work here, and in other places, it gives you this flexibility. So if I see that they react to learning English, there I am going to press them. (Kostas)

It is worth noting that Kostas finds Greek as important as English and that he would like his children to further develop Greek if they have 'free time'. Kostas's ideologies chime with De and Mejia's $(2002,51)$ reference to 'bi/multilingualism as a globalised phenomenon, involving an emergent global bi/multilingual elite consisting of 'generally well educated, upwardly mobile individuals who are proficient in two or more world languages ... and who in many cases ... have been in a position to forge a new global identity' In this context, the study of English is more often than not linked to notions of cosmopolitan citizenship, and the idea that children should learn to be 'global citizens' (Block 2014, 152). In a similar note, loannis links the mastery of English to his daughters' future 'prospects'. Asked whether he would prefer his daughters attend English or Greek classes, he explains:

I would put it (the emphasis) on English, I would think practically. Because we have to think of their prospects. They would need English even if they went to Greece. (loannis)

In family A, Fani and Stefanos's language planning for Katerina puts English to the forefront as well. Instead of Greek language classes at the complementary school, Katerina has English private lessons in the year the data were recorded:

This year, English took the place of Greek so there's no time for Greek. We have hired a very good English language teacher who gives her lessons privately at home. I can't deprive my child of the knowledge of English. I don't believe that there is a single parent out there who thinks that his/her child would compete in the workplace and in society without knowing English. (Fani)

Parental involvement in Katerina's language education includes alternating summer schools in England and France in order to provide her with opportunities to improve her French and English. When they take her to the cinema, they choose films in the original English version with French subtitles so that she can practise listening. As they feel that the Luxembourgish system does not support English as much as they wish for, they have already decided to send Katerina in 3 years' time to the only secondary school that offers the International Baccalaureate in English. 
These parental initiatives chime with Block's (2014) statement that becoming a global citizen is very much a middle class aspiration as it requires certain levels of symbolic capital (e.g. economic, cultural and social) as well as mobility (e.g. travel, study abroad programmes). Block $(2014,154)$ further explains:

commodification works as a way to capture a move from English as having use value to English as having exchange value, or better to English having both types of value. It exists as means of communication in ever changing social and geographical locations and is an objective skill that affords status, recognition and legitimacy to those who possess it.

\section{Reasons for maintaining Greek}

The parents' reasons for the maintenance of Greek are related to Duchêne and Heller's (2012) notions of 'pride' and 'profit'. In family B there are contrasting ideologies between the two parents, with Stefanos stressing the 'profit' of Greek language maintenance and Fani promoting the maintenance of Greek for reasons of 'pride'. Thus, Stefanos highlights the relevance of Greek for Katerina's future career as an interpreter or translator. According to Fani, he considers Greek an extra skill because it is a rare EU language. However, he does not consider the need for Greek language classes as he feels that exposure to Greek at home is adequate for the time being. Were she to become a translator, she would be able to improve her Greek literacy in a short period of time. By contrast, Fani considers Greek an important part of Katerina's identity and takes care of Katerina's improvement of Greek. In the past, she used to teach her daughter herself. In the first interview, at the beginning of the school year, she confessed that she 'felt bad' because Katerina did not have any Greek lessons. After the Christmas break, she found her a private Greek language tutor.

Maria and loannis appear to be the keenest with regard to Greek language maintenance. Although the girls are fluent Greek users as they moved to Luxembourg 15 months prior to the start of the study, at the ages of 7, 10 and 12, the parents send the girls to the Greek complementary school. As mentioned previously, they consider Greek as an inextricable part of the girls' identity, but like Stefanos, they also perceive Greek as an extra asset of instrumental value and link it to tangible qualifications in the form of language certificates. Using these arguments, they try to persuade the girls who are less interested in attending Greek classes.

M: $\quad$ But this year none of them wanted to attend the Greek mother tongue classes. None.

Researcher: Did they say why?

M: What do I need mother tongue school for? I know Greek. And also: what I need Greek for? Who will I speak it with? We live here now, and we don't think we're going to return to Greece.

Researcher: What do you say to that?

M: I tell them it's not right, you may need it one day, like my eldest one who sat Greek exams last year and got the B2 certificate at a university in Germany. She got it with top grade. (Maria, 40)

The excerpt above is indicative of these Greek parents' deep-seated belief that foreign language instruction equals foreign language certification (Dendrinos, Karavas, and Zouganelli 2013).

Kostas and Sofia are the only parents who do not send and do not plan to send their children to Greek language classes as the 'challenge for them is to master Luxembourgish, French and German within a 5-year-period'. Kostas devotes a lot of time going over his elder's son German homework, because, as he says 'I enjoy it, and it is a chance for me to improve my German along with my son'. By contrast, Sofia cannot supervise homework owing to her lack of knowledge of German. To support the children, she decided to have them watch German TV instead of Greek. However, the boys were not interested in watching children's programmes in a language other than Greek. 
They are fluent in spoken Greek as they moved to Luxembourg 15 months prior to the start of the study. Nevertheless, Kostas does not neglect the teaching of Greek. He does so through playing games such as riddles and hangman, and through reading stories. Both parents hold practical and utilitarian reasons for the maintenance of Greek:

Who knows? They may tell me in the future that they want to study at a Greek university. They won't be able to do that if they don't know how to read and write in Greek. (Sofia)

Further, Kostas believes that his children need to know Greek in case he loses his job and they have to return to Greece. Finally, Kostas believes that the Greek section of the European School, which will ensure access to university, is a good alternative to the state secondary school. This implies developing the children's literacy skills in Greek to a high level:

According to the plan we have designed with Sofia, we might need to send our children to the Greek section of the European school later on. But this will depend of course on our work with teaching them Greek at home. If their level is good enough, that is. It means we want to have this choice, if we see that the boys haven't done well at Luxembourgish school .... (Kostas)

Nevertheless, like the other parents, he would like his children to enrol later into a grammar school (lycée classique), which opens the door to Higher Education. The parents are aware of the high linguistic demands placed on pupils in Luxembourg. Only children with high competences in German and French can enrol in grammar schools. Hence, planning ahead, they both support the development of school languages and of Greek.

\section{Concluding remarks}

This study has shown that the Greek parents hold very positive beliefs about multilingualism in general and multilingual education in Luxembourg. The parents studied by Chatzidaki and Maligkoudi (2013), Curdt-Christiansen (2009) or King and Fogle (2006) similarly perceived bilingualism as an asset. Further, the Greek parents understand the role of languages for integrative and career purposes as well as for citizenship. When they mention that they envisage a 'European citizen' model for their children, in essence, they make reference to 'the notion of the neoliberal citizen which links neoliberal economic policies with the development of cosmopolitan citizenship in education' (Park 2009).

Similar to the parents studied by Chatzidaki and Maligkoudi (2013) and Curdt-Christiansen (2009), all the Greek parents actively invest in their own language learning and that of their children. They expect their children to achieve high academic standards and are involved in the children's school and educational lives, for example, by helping with school work, making arrangements for private tuition or paying for summer schools abroad. Hence, their language ideologies, which are the driving force behind family language policies (Curdt-Christiansen 2009), are enacted in language practices and language management (King, Fogle, and Logan-Terry 2008).

The Greek parents' ideologies reflect Horner's (2011) discussion of language ideologies in Luxembourg to some extent. Horner holds that the Luxembourgish society values individual multilingualism in standard languages with a value exchange at the linguistic market at the expense of other forms of multilingualism. Greek is not considered to be a valued social capital. The Greek parents certainly hold strong beliefs regarding the significance of hegemonic, 'standard' languages such as French, German and English and they actively invest in the development of skills in these languages. However, they also value their ethnic language (Chatzidaki and Maligkoudi 2013) and continue to develop it for reasons as diverse as identity, culture and future careers outside Luxembourg. Greek is both an important marker of ethnocultural identity and a useful 'extra linguistic asset', which might potentially lead to higher education or to a career with languages. Still, the findings show, that, unlike earlier Greek migrants in the USA, Australia and some parts of Europe, the maintenance and development of Greek is not a priority for parents in this study. 
The parents' discourse about the functions of languages shows that their language ideologies are informed by the notion of language commodification whatever their length of settlement in Luxembourg. They emphasise the need to master German, French and English and praise the educational system for developing these. They further believe that knowledge of Luxembourgish, useful for integration, is irrelevant for the international job market. They appear oblivious to its importance for the national job market. Good language skills in Luxembourgish are required in many jobs such as banks, administrative positions, etc. The fact that Greek parents in this study do not emphasise their children's development in the national language shows that they think globally rather than locally.

This ethnographic study is one of the first contributions to a sociolinguistic understanding of the challenges and benefits that the new migrations from the South to the North-west of the EU pose to migrant families. This study will be the first of a number to examine the factors that shape the linguistic ideologies, repertoires and practices of migrants from Southern EU countries in the current conditions of the globalised new economy.

\section{Acknowledgements}

The authors would like to thank Professor Jean Jacques Weber for reading earlier versions of this manuscript. Many thanks are also due to Antony Warde-Jones for his valuable help with proofreading as well as to the two anonymous referees for their very useful comments.

\section{Disclosure statement}

No potential conflict of interest was reported by the authors.

\section{Funding}

This work was supported by the Fonds Nationales de la Recherche Luxembourg [grant number 6791471].

\section{Notes on contributors}

Nikos Gogonas is a postdoctoral fellow at the Institute of Applied Educational Sciences, University of Luxembourg. Claudine Kirsch is an Associate Professor of Languages/Linguistics and Education at the University of Luxembourg.

\section{References}

Appadurai, A. 1996. Modernity at Large: Cultural Dimensions of Globalization. Minneapolis: University of Minnesota Press. Bernard, H. Russell, and Gery W. Ryan. 1998. "Text Analysis: Qualitative and Quantitative Methods." In Handbook of Methods in Cultural Anthropology, edited by H. Russell Bernard, 595-646. Walnut Creek, CA: Altamira Press.

Block, D. 2014. Social Class in Applied Linguistics. Oxford: Routledge.

Brennan, S. 2013. "De l'indépendance politique à la crise économique actuelle: un regard sur la promotion institutionnelle de l'irlandais." Langage et société 3 (145): 35-53.

Cameron, D. 2012. "The Commodification of Language: English as a Global Commodity." In The Oxford Handbook of the History of English, edited by T. Nevalainen and E. Traugott, 352-364. Oxford: Oxford University Press.

Charmaz, K. 2006. Constructing Grounded Theory: A Practical Guide Through Qualitative Analysis. 2nd ed. London: Sage.

Chatzidaki, A. 1996. "Greek as a Minority Language in Western Europe, 'weak' or 'strong'?" In 'Strong' and 'weak' Languages in the European Union: Aspects of Linguistic Hegemony, 95-104. Thessaloniki: Centre for the Greek Language, [in Greek].

Chatzidaki, A., and C. Maligkoudi. 2013. "Family Language Policies among Albanian Immigrants in Greece." International Journal of Bilingual Education and Bilingualism 16 (6): 675-689.

Chew, P. G. L. 2010. "Linguistic Capital, Study Mothers and the Transnational Family in Singapore". In Globalization of Language and Culture in Asia: The Impact of Globalization Processes on Language, edited by V. Vaish, 82-106. London: Continuum.

Corbin, J., and A. Strauss. 2008. Basics of Qualitative Research: Techniques and Procedures for Developing Grounded Theory. 3rd ed. Thousand Oaks, CA: Sage. 
Crouch, M., and H. McKenzie. 2006. "The Logic of Small Samples in Interview-Based Qualitative Research." Social Science Information 45 (4): 483-499.

Curdt-Christiansen, X. L. 2009. "Invisible and Visible Language Planning: Ideological Factors in the Family Language Policy of Chinese Immigrant Families in Quebec." Language Policy 8: 351-375.

Da Silva, E., M. McLaughlin, and M. Richards 2007. "Bilingualism and the New Globalized Economy: The Commodification of Language and Identity." In Bilingualism: A social Approach, edited by M. Heller, 183-206. London: Palgrave Macmillan.

De Mejia, A.-M. 2002. Power, Prestige and Bilingualism. Clevedon: Multilingual Matters.

Dendrinos B., E. Karavas, and K. Zouganelli. 2013. European Survey of Language Competences: Greek National Report. RcEL, University of Athens.

Dialektopoulos, A. 2003. "Van tween een bicultureel-tweetalige socialisatie van Griekse Leerlingen in Nederland." Published PhD thesis, University of Groningen.

Droulia-Mitrakou, E. 2006. "Luxembourg." In Greeks in the Diaspora, 134-135. Athens: Hellenic Parliament Publications. [in Greek].

Duchêne, A., and M. Heller, eds. 2012. Language in Late Capitalism: Pride and Profit. New York: Routledge.

Fishman, J. A. 1966. Language Loyalty in the United States. The Maintenance and Perpetuation of Non-English MotherTongues by American Ethnic and Religious Groups. The Hague: Mouton.

Gee, P., G. Hull, and C. Lankshear. 1996. The New Work Order: Behind the Language of the New Capitalism. Boulder, CO: Westview Press.

Giddens, A. 1991. The Consequences of Modernity. Cambridge: Polity Press.

Heller, M. 2003, "Globalization, the New Economy, and the Commodification of Language and Identity." Journal of Sociolinguistics 7 (4): 473-492.

Heller, M. 2010. "The Commodification of Language." Annual Review of Anthropology 39: 101-114.

Heller, M., and A. Duchêne. 2012. "Pride and Profit: Changing Discourses of Language, Capital and Nation-State." In Language in Late Capitalism: Pride and Profit, edited by Alexandre Duchêne and Monica HellerNew, 1-21. York: Routledge.

Holborow, M. 2015. Language and Neoliberalism. Abingdon: Routledge.

Horner, K. 2011. "Media Representations of Multilingual Luxembourg. Constructing Language as a Resource, Problem, Right and Duty." Journal of Language and Politics 10 (4): 491-510.

Horner, K., and J. J. Weber. 2008. "The Language Situation in Luxembourg." Current Issues in Language Planning 9 (1): 69 121.

Huang, S., and B. S. A. Yeoh. 2005. 'Transnational Families and Their Children's Education: China's 'Study Mothers' in Singapore". Global Networks, 5: 379-400.

King, K. A., and L. Fogle. 2006. "Bilingual Parenting as Good Parenting: Parents' Perspectives on Family Language Policy for Additive Bilingualism." International Journal of Bilingual Education and Bilingualism 9: 695-712.

King, K. A., L. Fogle, and A. Logan-Terry. 2008. "Family Language Policy." Language and Linguistics Compass 2: $907-922$.

Kroskrity, P. V. 2004. "Language Ideologies." In Companion to Linguistic Anthropology, edited by A. Duranti, 496-517. Malden, MA: Basil Blackwell.

Labrianidis, L., and N. Vogiatzis. 2013. "Highly Skilled Migration: What Differentiates the 'Brains' Who Are Drained from Those Who Return in the Case of Greece?" Population, Space and Place 19 (5): 472-486.

Lee, W. M. 2016 "'Gangnam Style' English Ideologies: Neoliberalism, Class and the Parents of Early Study-Abroad Students." International Journal of Bilingual Education and Bilingualism 19 (1): 35-50. doi:10.1080/13670050.2014.963024.

Moschonas, S. 2004. "Relativism in Language Ideology: On Greece's Latest Language Issues." Journal of Modern Greek Studies 22: 173-206.

Nikolaou, S. 2013. "Kindheit und Wirtschaftskrise in Griechenland: Eine explorative Analyse der Presseberichterstattung ausgewählter Tageszeitungen." Diskurs Kindheits- und Jugendforschung 8 (2): 231-235.

Norton, B. 2013. Identity and Language Learning. 2nd ed. Extending the Conversation. Bristol: Multilingual Matters.

Park, J. S. Y. 2009. The Local Construction of a Global Language: Ideologies of English in South Korea. Berlin: Mouton de Gruyter.

Park, J. S., and A. Lo. 2012. "Transnational South Korea as a Site for Sociolinguistics of Globalization: Markets, Timescales, Neoliberalism." Journal of Sociolinguistics 16 (2): 147-164.

Paulston, C. B. 1986. "Social Factors in Language Maintenance and Language Shift." In The Fergusonian Impact. Festschrift in Honour of Charles A. Ferguson (Vol. 2), edited by J. A. Fishman, A. Tabouret-Keller, M. Clyne, B. Krishnamurti, and M. Abdulaziz, 493-511. New York: Mouton de Gruyter.

Pujolar, J. 2007. "Bilingualism and the Nation-State in the Post-National Era." In Bilingualism, edited by Monica Heller, 7195. New York: Palgrave Macmillan.

Rahman, T. 2009. "Language Ideology, Identity and the Commodification of Language in the Call Centers of Pakistan." Language in Society 38 (2): 233-58.

Smolicz, J. J., and M. J. Secombe. 1988 "Types of Language Activation and Evaluation in an Ethnically Plural Society." In Status and Function of Languages and Language Varieties, edited by U. Ammon, 478-511. Berlin: De Gruyter. 
Smolicz, J., M. Secombe, and D. Hudson. 2001. "Family Collectivism and Minority Languages as Core Values of Culture among Ethnic Groups in Australia." Journal of Multilingual and Multicultural Development 22 (2): 152-172.

Tamis, A. 2005. The Greeks in Australia. Cambridge: Cambridge University Press.

Tamis, A. M. 2009. "The Greek Language in the Diaspora/La langue Grecque en Diaspora." Études Helléniques 17 (1): 1-19. Tan, P. K. W., and R. Rudby, eds. 2008. Language as Commodity: Global Structures, Local Marketplaces. London: Continuum. Triandafyllidou, A., and R. Gropas. 2014. "Voting With Their Feet': Highly Skilled Emigrants from Southern Europe." American Behavioral Scientist 58 (12): 1614-1633.

Veltman, C. 1983. Language Shift in the United States. New York: Mouton-de Gruyter.

Weber, J. J. 2009. Multilingualism, Education and Change. Frankfurtam Main: Peter Lang.

Woolard, K. 1998. "Introduction: Language Ideology as a Field of Inquiry." In Language Ideologies: Practice and Theory, edited by B. Schieffelin, K. Woolard, and P. Kroskrity, 3-47. New York: Oxford University Press. Accessed September 2015. www.statistiques.public.lu. 